IIIIIIIIIIIIIIIIIIIIIIIIIIII

$$
\text { ミニレビュー }
$$

|IIIIIIIIIIIIIIIIIIIIIIIIIII

\title{
昆虫の視覚と害虫防除
}

\author{
八 瀬順也* \\ 兵庫県立農林水産技術総合センター
}

（2020年7月 13 日受理）

\section{Characteristics of insect vison and it's use for pest control}

\author{
Junya YASE \\ Hyogo Prefectural Research Institute for Agriculture, Kasai, Hyogo 679-0198, Japan
}

Keywords: insect vision, pest control, yellow lamp, color trap, sticky trap.

\section{は じめに}

地球上に生息している昆虫の種類は, 既知種だけで 100 万 種を超える．昆虫は地球上でもっとも多様性に富んだ生物群 といえるだろう。今日，「生物多様性」は農業においても無 視できないキーワードになっているが, 農業はこれら多様性 を極めた昆虫たちとのせめぎ合いでもある.

20 世紀の半ばに登場した化学合成農薬によって農作物の 生産は安定し, われわれは多大な恩恵を受けてきた。しかし 現在,「環境への配慮」と「安全な農作物」が求められる中 で, 害虫防除は化学合成農薬のみに依存しない手段が求めら れている。

本稿では, 昆虫の視覚特性と行動の関係から害虫防除のア プローチを考え，物理的防除技術としての展開を紹介した い.

\section{1. 誘蛾灯の歴史}

多くの昆虫は光に集まる性質を持っている。このことを害 虫防除に利用するアイディアは，古くは江戸時代に見ること

\footnotetext{
\#第44回大会シンポジウムを取りまとめた解説.

* \% 679-0198 兵庫県加西市別府町南ノ岡甲 1533

E-mail: junya_yase@pref.hyogo.lg.jp

(c) 日本農薬学会
}

ができる. 水田周辺で松明を持って練り歩く「虫追い」の行 事 ${ }^{1)}$ は, 儀式的な意味合いもあったが, 害虫の灯火誘殺を 狙ったものであった（図1). その後, より実用性を求めて

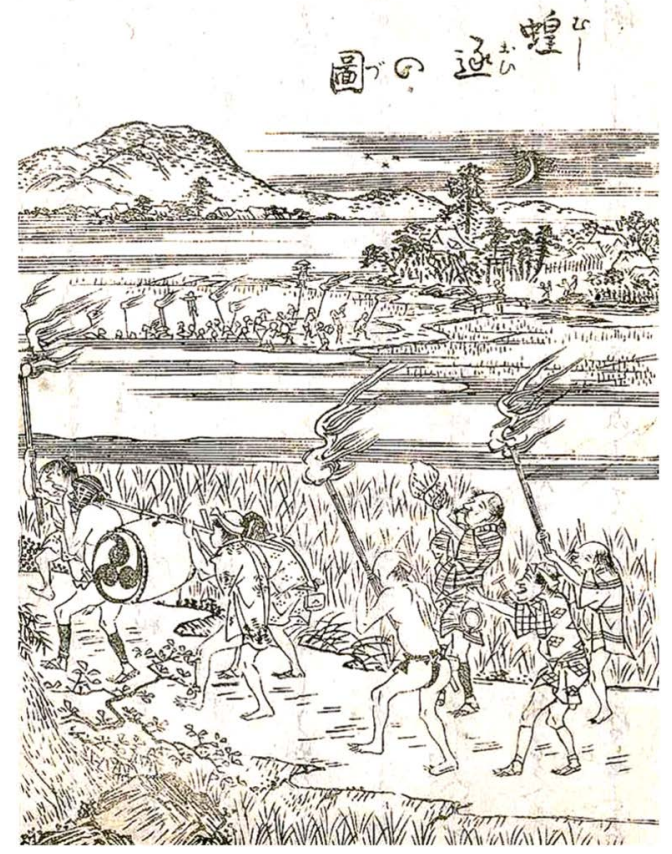

図1. 虫追いの図. 文献1）より. 


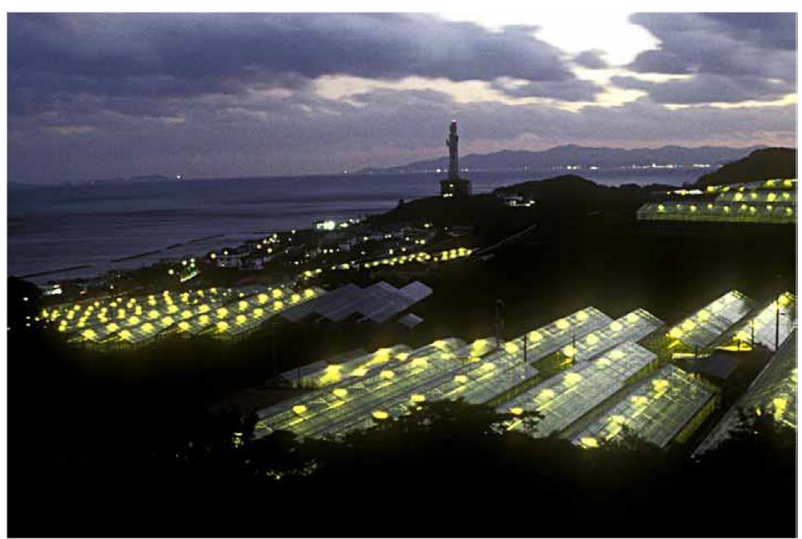

図2. 黄色灯を点灯しているカーネーション施設群．撮影：淡 路島, 1996年.

松明は箠火（かがりび）に変わり, 明治時代以降は石油ラン プ, アセチレンランプ，白熱電灯と新しい光源が使用されて いった．昭和初期には，短波長の光が二カメイガに対して誘 引能力が高いことが明らかにされ，誘蛾灯として青色蛍光灯 が開発された。

青色蛍光灯の普及が急速に進んだのは食料増産が急務だっ た終戦直後であったが，その最中に占領軍総司令部（GHQ） から，「益虫も誘殺されるので有害」として誘蛾灯の普及に 対して中止が求められた。 またこの頃から，DDTやパラチ オンなどの化学合成農薬の使用が始まり, 誘蛾灯そのものの 利用は衰退の方向へ向かっていった. ${ }^{2,3)}$

\section{2. 防蛾灯としての黄色灯の利用}

1960 年代， $580 \mathrm{~nm}$ に波長ピークを持つ黄色光が果樹の果 実を加害する吸が類成虫（アケビコノハやアカエグリバな ど）対して優れた行動阻害を示すことが明らかにされた。 ${ }^{4}$ 利用方法として，最低照度 $1 \mathrm{x}$ 以上，この条件を満たすため の目安として $10 \mathrm{a}$ 当たり 7灯 $(40 \mathrm{~W}$ 蛍光灯で）という夜間 照明の基準が作られ，ナシ，リンゴ，モモなどで広く普及が 進んだ.5)

1990年代に入り，果樹以外で黄色灯が利用されるように なった．事例としては，カーネーションのシロイチモジョ トウ ${ }^{6)}$ が抢そらく最初だと思われる。その後，青ジソの八 スモンヨトウ, ${ }^{7)}$ スイートコーンのアワノメイガ8) で試みら れ，これらは花き・野菜類における黄色灯利用の先駆的事例 となった。

果樹の吸力゙類防除では成虫が加害者であり，直接の防除対 象であったが，花き・野菜類の黄色灯の利用では，ガ類成虫 の交尾・産卵を妨げて次世代幼虫密度を減らすことで被害軽 減効果を得ている，説明されるとごく当たり前に思えるが， 技術開発に携わる者として，果樹での利用からこのブレイク スルーに至るまで，実に約 30 年を要したことを特記してお
きたい

1990年代には黄色灯にとってもう一つ重要な出来事が起 こっている.1994年は西日本を中心にオオタバコガが大発 生し，深刻な問題になった年であった。この年に淡路島の カーネーションでオオタバコガを対象にした黄色灯の試験が 行われ, 難防除害虫である本種に対して優れた効果があるこ

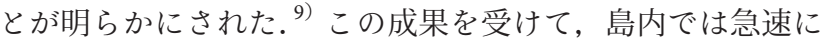
普及が進み（図2），全国的に注目されるようになって，各 地でいろいろな作物, 害虫に対して利用が取り組まれた ${ }^{10)}$ （表1）。その後は, 高圧ナトリウムランプ等のHID ランプ （High Intensity Discharge lamp）を光源とした防蛾灯によっ て, 露地での効率的な広域設置が可能になり，さらに近年で は光源の LED化が進んでいる.

表 1. 黄色灯の利用が試みられた主な害虫と作物*.

\begin{tabular}{|c|c|}
\hline 害虫 & 作物 \\
\hline $\begin{array}{l}\text { アケビコノ八, アカエグリバ, } \\
\text { ヒメエグリバなどの果樹吸 } \\
\text { 蛾類** }\end{array}$ & ナシ, リンゴ, モモ, ブドウ \\
\hline シロイチモジヨトウ & カーネーション, トルコキキョウ \\
\hline ハスモンヨトウ & $\begin{array}{l}\text { バラ, キク, シクラメン, トルコ } \\
\text { キキョウ, ブドウ, イチゴ, レタ } \\
\text { ス, アスパラガス, ピーマン, オ } \\
\text { オバ (葉ジソ) }\end{array}$ \\
\hline オオタバコガ & $\begin{array}{l}\text { カーネーション, キク, シクラメ } \\
\text { ン, トマト, ナス, ピーマン, } \\
\text { タス }\end{array}$ \\
\hline イラクサギンウワバ & キャベツ, エンドウ \\
\hline ハイマダラノメイガ & キャベツ, ダイコン \\
\hline アワノメイガ & スイートコーン, ショウガ \\
\hline ベニフキノメイガ & オオバ（葉ジソ） \\
\hline コクロヒメハマキ & オオバ（葉ジソ） \\
\hline スジキリヨトゥ & シバ \\
\hline チャノホソガ & チャ \\
\hline チャノコカクモンハマキ & チャ, ブドウ \\
\hline チャハマキ & チャ \\
\hline モモノゴマダラノメイガ & ブドウ, モモ \\
\hline トビイロトラガ & ブドウ \\
\hline モンキクロノメイガ & ブドウ \\
\hline ナシヒメシンクイ & ナシ \\
\hline アズキノメイガ & ナス \\
\hline フキノメイガ & ナス \\
\hline チャバメアオカメムシ & ナシ, カキ \\
\hline
\end{tabular}

*試験のみの事例や効果について未判定なものを含む。**成虫によ る直接加害の阻止．文献10）ょり引用. 


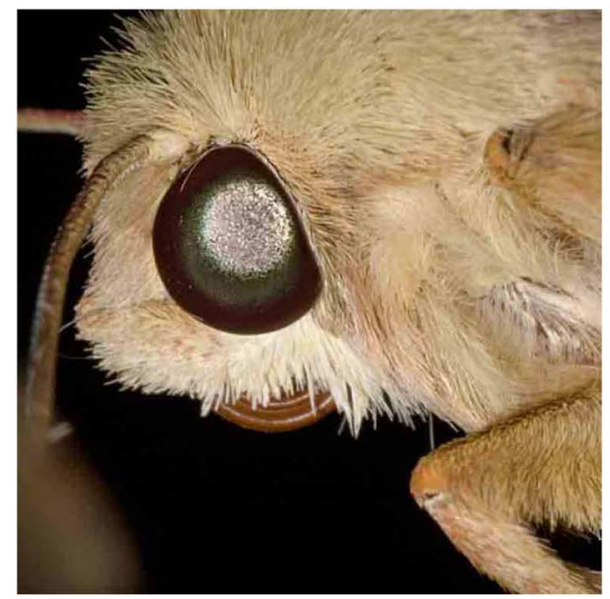

暗適応時

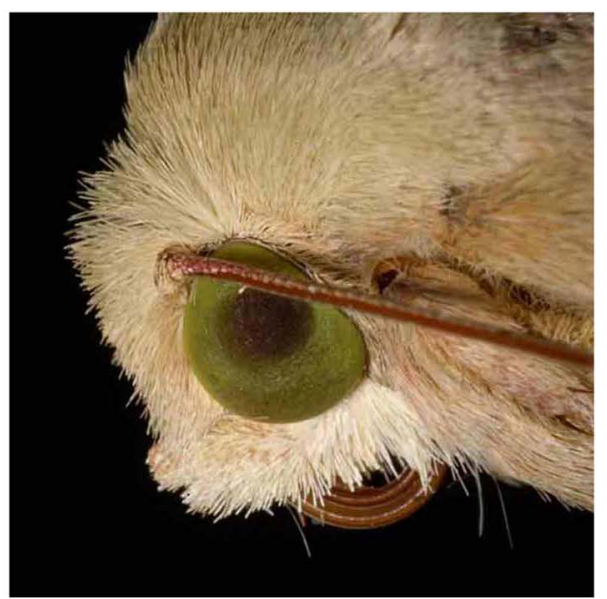

明適応時

図3. 暗適応時と明適応時の複眼の様子.オオタバコガ.

\section{3. 黄色灯の作用原理}

夜行性ガ類（ヤガ類）の活動性は複眼の状態と連動してい る. 周囲が暗い環境では，光をあてると複眼内部からの反射 光で中央部か輝いているように見え，このときは活発な状態 にある（暗適応；図3左）。一方，明るい環境では複眼内部 が色素で覆われるため反射が生じなくなり，同時に不活発な 状態になる (明適応; 図3右). 黄色灯の作用は, 明適応の 誘導を狙ったものであり，黄色光が用いられる理由は，光源 として誘虫性が低いことと，明適応に要する時間が他の波長 と比べて短いことによる. ${ }^{4)}$

こうした害虫の活動抑制を目的とした光防除技術は，国外 での事例を見ないので，日本独自の技術と言える.

\section{4. 色を利用した害虫防除}

光の利用に対して，農業害虫の防除に色を利用するように なったのは比較的新しく，その取り組みは1980年ごろから 始まっている. ${ }^{11)}$ 手段としては, 特定の色彩が昆虫類に対し て示す誘引性を利用して捕殺するのが一般的で，色彩面に粘 着剂を塗布したものが主に使われている。このような資材を 本稿では「色彩トラップ」と乎ぶことにして，ここからは昆 虫の色彩誘引のメカニズムについて考えるとともに，色彩卜 ラップの利用について述べる.

\section{5. 色という感覚}

色は物体における光の反射として知覚されるもので，この 情報を利用することで，生き物は環境に対する高度な適応を 可能にしている.

われわれは, 色に対する感覚を白, 黄, 赤色といった表 現で共有しているが，そもそも色は主観的な感覚であり，他
の生き物が持つ色彩感覚を共有することは難しい，例えば紫 外光の反射率の異なる 2 種類の白色では, ヒトはおよそ波長 $400 \mathrm{~nm}$ 以下 (紫外光) の光は感知できないので, ${ }^{12}$ ) 紫外光 を多く反射する資材（図 4: A）と，ほとんど反射しない資材 （図 4: B）は色彩的に区別できない，ところが，多くの昆虫

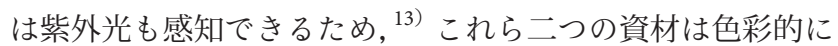
異なって見えていると考えられる.

一例として，著名な野菜害虫であるミナミキイロアザミウ マでは，同じ白色でも紫外光を反射する資材は誘引性が低 く，紫外域を反射しない白色資材では誘引性が高いことが 知られていて, ${ }^{11)}$ 色に対する昆虫の行動を考える場合, 前記 の両資材をヒトの主観で报うことは適切ではないことがわ かる。 また, 昆虫は多くの種で, ヒトの赤色に当たるおよそ $600 \mathrm{~nm}$ 以上の波長が感知できないこともよく知られており, 昆虫は, その固有の視覚感度のなかで, 独自の色彩世界を 持っている（と想像するしかない）（図5).

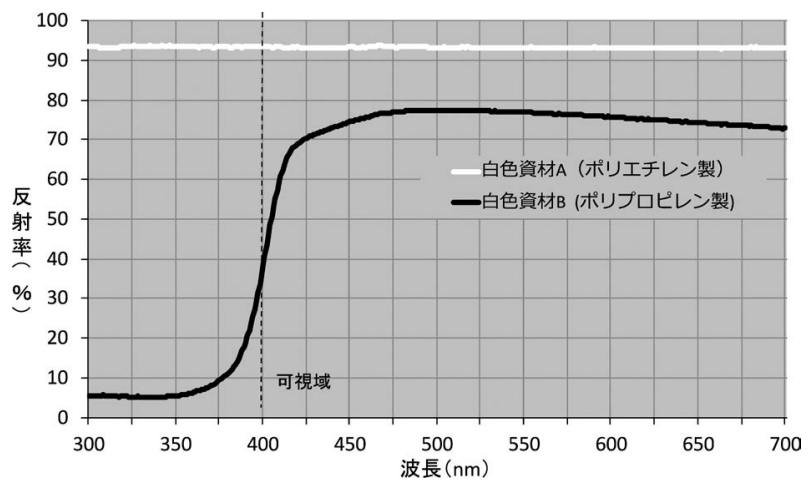

図4. 白色資材 2 種の分光反射特性. 


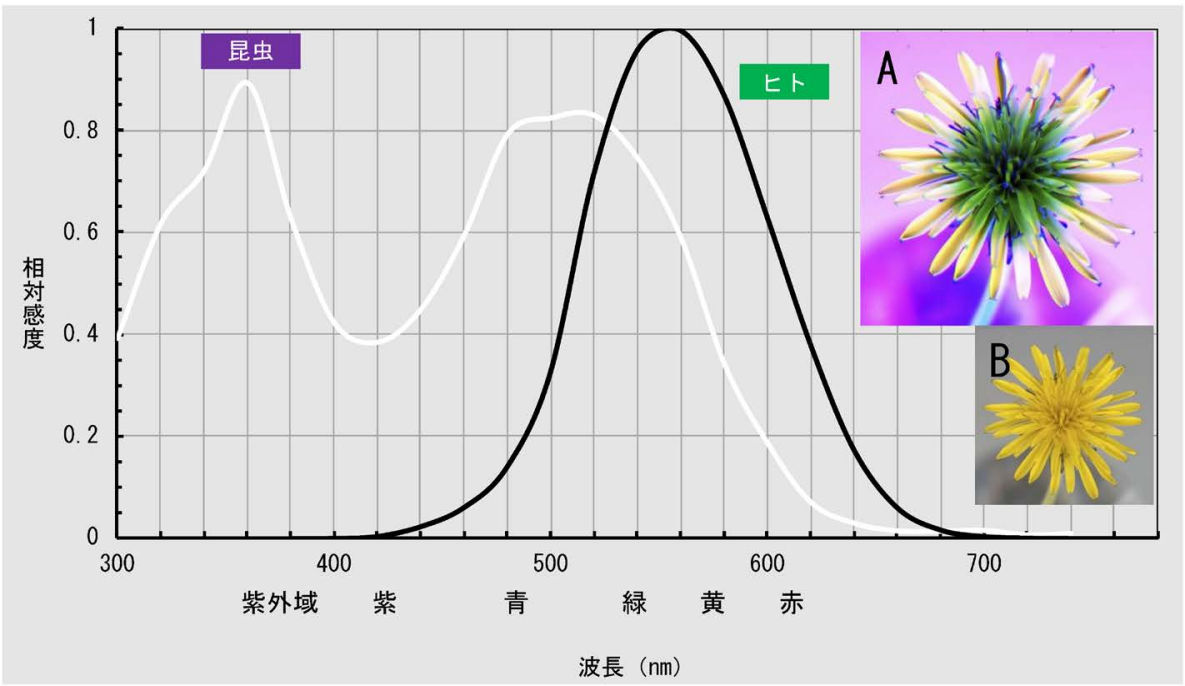

図5. 昆虫及びヒトの分光視感度とそれに基づくタンポポの画像. 分光感度は文献12）からネギアザミウマのものを，ヒトは文献11）から 引用.（A）昆虫の分光視感度に基づく画像. 紫外域の波長を赤色に変換してRGB合成している.(B) ヒトの分光視感度に基づく，いわゆる可 視光画像. タンポポの花は, ヒトの視覚では黄色の単色に見えるが, 紫外域を可視化して見ると, 中心付近に紫外光を吸収している部分が あることがわかる．昆虫はタンポポの花に模様をみていると考えられる。（color online）

\section{6. 色彩トラップという防除資材}

色彩トラップは，害虫を視覚的に誘引して捕殺する物理的 防除資材である。主な対象害虫は，微小害虫と呼ばれるアザ ミウマ類, コナジラミ類, アブラムシ類そしてハ工類（ハモ グリバエ類，キノコバエ類）で，成虫の自発的な飛翔によっ て捕獲される。

多くの製品が市販されているが，サイズは $25 \times 10 \mathrm{~cm}$ 前後 で，形状は長方形，色彩については青色または黄色が多い， 害虫ごとの適用色を打扔まかに整理すると，アザミウマ類： 青色抒よび黄色，コナジラミ類：黄色，アブラムシ類：黄 色，八モグリバエ類：黄色となっていて，黄色が高い汎用性 を示している。

色彩トラップの形状と誘引性の関係は, 弘中・針山 ${ }^{14)}$ が まとめたところでは，アザミウマ類やコナジラミ類に対して は三角形や円形の誘引性が高いとの報告がみられるが，製品 としては材料の無駄が少ない四角形が多く採用されているよ うである。また，防除資材としては捕獲作用を受け持つ粘着 剤の性能も重要であり, 製品では使用者の利便性も考慮して 工夫されている。

\section{7. 色彩トラップヘの定位行動}

昆虫の視力（空間分解能）はミツバチで 0.01 程度と推定 されており, ${ }^{15)}$ アザミウマ類やコナジラミ類といった微小で 複眼サイズの小さい昆虫類ではさらに劣ると思われる。飛翔 能力も高い上うには思えないが，色彩トラップへの定位行動 はどのように行われているのだろうか.

微小な昆虫はやみくもに飛翔しているように見えるが,
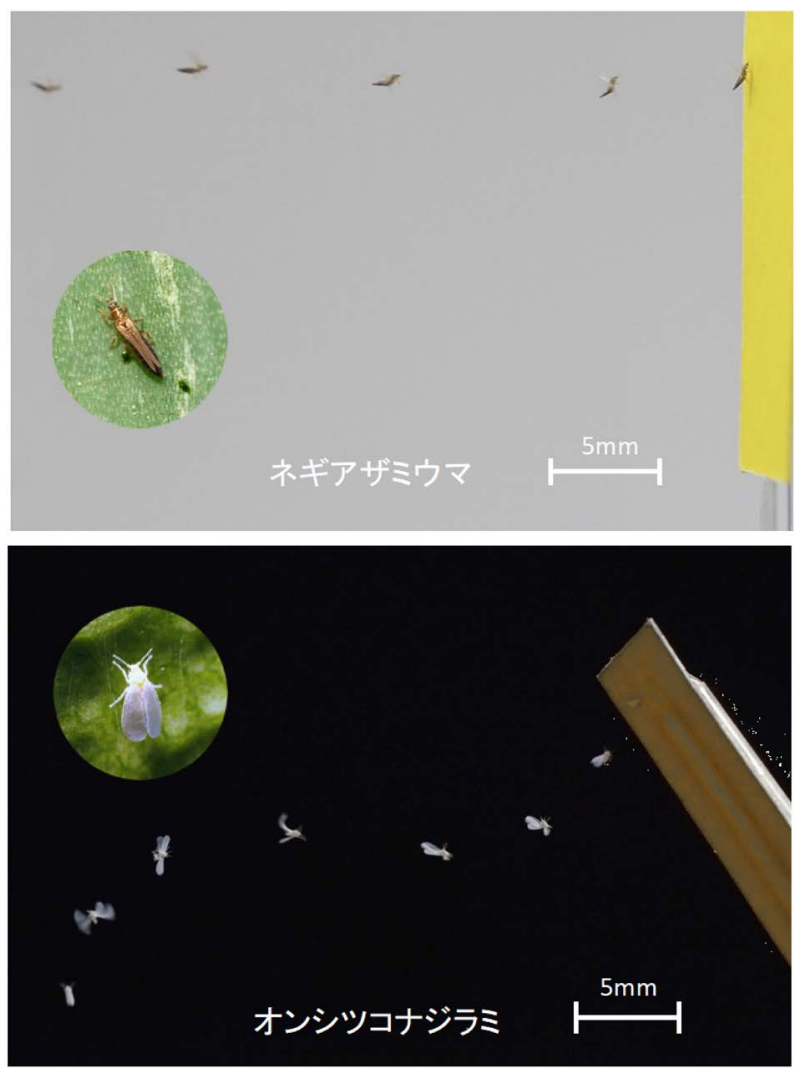

図6. ネギアザミウマおよびオンシツコナジラミの定位飛翔. 黄色シートを目標物として，1/60秒ごとの同一フレーム画像を 1 枚に合成したもの. 


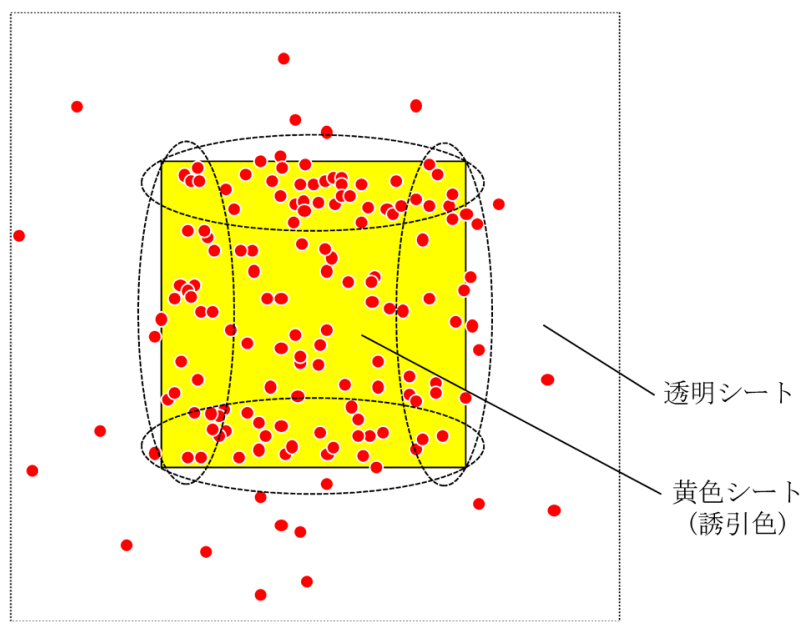

図7. 粘着シート上のオンシッコナジラミ成虫捕獲点の分布. 赤丸が捕獲点を示す. 黄色部 $10 \times 10 \mathrm{~cm}$, 透明部 $20 \times 20 \mathrm{~cm}$. 破線 で囲った部分での捕獲が多い.

実は姿勢を制御しながら目標に対して正確に定位している (図6). 粘着シート上の捕獲点を調べてみると, 誘引色の周 辺部に多い傾向が見られ，色彩部と背景で作られる視覚コン トラストの境界が視覚目標として使われている様子がうかが われる (図 7)。誘引源が光源の場合でも, 多くの昆虫種で 発光部と背景によって生じる視覚コントラストの境界に強

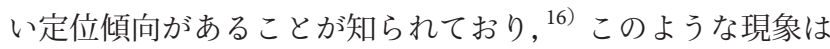
(視覚的) エッジ効果と呼ばれている. ${ }^{17)}$

\section{8. エッジ効果の利用}

ネギアザミウマを対象にした試験では，色彩トラップの両 側に白色または黒色の視覚コントラストを配置すると, 誘虫 数が有意に多くなるという結果が得られている ${ }^{18)}$ (図 8). 前 述したように, 目標物への定位には視覚コントラストの存在 が重要な役割を担っているので，このように視覚コントラス 卜を加えることで, エッジ効果による誘引性能の向上が期待 できる。

エッジ効果を利用した色彩トラップの製品も開発されて いる. 図9の製品では，既製品の色彩トラップをべースと して, 濃淡を分けた淡緑色のひし形模様が印刷されている. 模様の色彩と数は捕虫効率において最適化が図られており, ベースとなった模様のないタイプとの比較では, 1枚（両 面）当たりの捕薮がコナジラミ類でおよそ 1.6 倍向上して いる. ${ }^{19)}$

このようなエッジ効果を示す模様の付加は, 色彩トラップ 誘引性能を向上させるだけでなく, 設置場所の背景に依存し ない独立した視覚コントラストを持つことから, 安定した視 認性か得られるので, 密度消長を調べる発生モニタリングの ような用途にも適していると考えられる。

\section{おわりに}

昆虫類の視覚的な行動は, 機械的に生じているわけではな く，弘中・針山 ${ }^{14)}$ が指摘しているように，昆虫種および環 境条件や生理状態ごとに, 異なるメカニズムで引き起こされ ていると考えるべきである．害虫防除技術として捕獲を目的

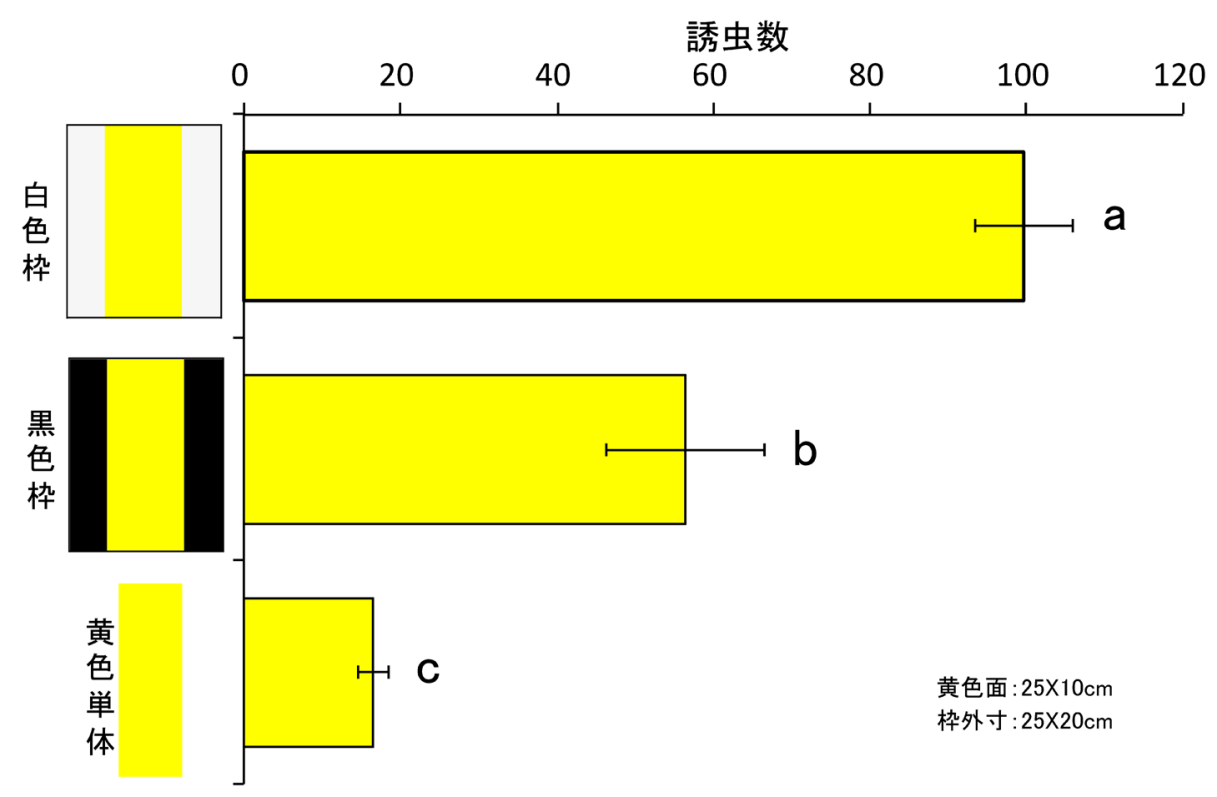

図 8. 視覚コントラストを配置した黄色トラップにおけるネギアザミウマの誘虫数比較. 文献17）から改変. 各 8 反復，黄色面 1 枚あたりの 平均誘虫数土標準誤差. 異なるアルファベット間には有意差が認められる（Tukey’s test, $p<0.01$ ). 


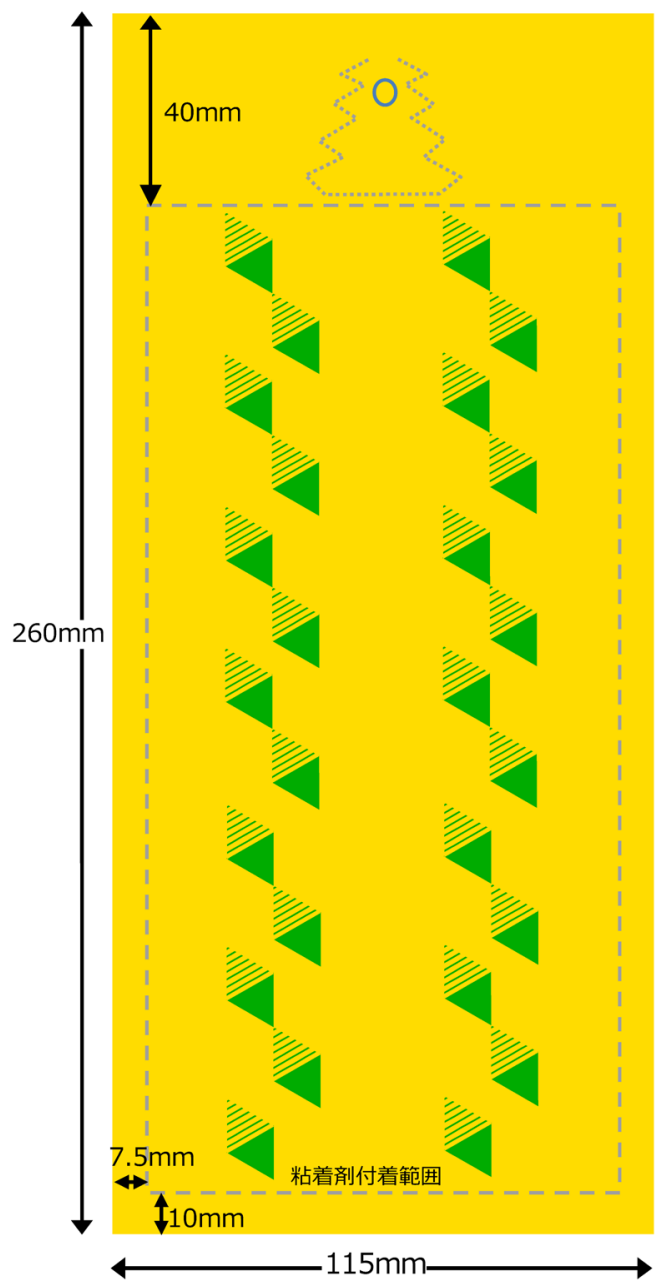

図9.エッジ効果を採用した色彩トラップの製品例．商品名： ラスボスRタイプ／大協技研工業.

とするのであれば，例えば振動などの刺激で作物から害虫の 離脱を促すなど，さらに効率を上げるために他の手段との組 合せを検討する余地がある，その一方で，天敵や授粉昆虫等 の有用昆虫への影響を最小限に抑えることを考慮しておく必 要もあるだろう.

五感と呼ばれるもののうち, 視覚はもっとも距離をおいて 作用する．害虫の出現は，ほとんどの場合，人の行為が招い たものなので，適正な「間合い」をとる責任はやはり人にあ る（そもそも昆虫にはそんな意識はないだろう）。間合いは
広ければ広いほど，お互いへの干渉は少なくなる．視覚の利 用は，まさにこの適正な間合いをとるのに最適なアプローチ の一つだと考えている.

\section{引 用 文 献}

1) 大蔵永常, 除蝗録, 1826.

2) 石倉秀次：誘蛾燈史, 日本植物防疫協会, p. 164, 1991.

3）江村 薰他：黄色灯による農業害虫防除, 農業電化協会, p. 135, 2004.

4) 野村建一他：日本応用動物昆虫学会誌 9, 179-186 (1965).

5) 内田正人：農業および園芸 58, 57-63 (1983).

6) 矢野貞彦：関西病虫害研究会報 34, 97 (1992).

7）田中 寬他：関西病虫害研究会報34, 47-48 (1992)。

8) 那波邦彦, 向阪信一: 日本応用動物昆虫会学会中国支部会報 37 , 19-24 (1995).

9）八瀬順也他：日本応用動物昆虫会学会中国支部会報 38, 1-7 (1996).

10) 八瀬順也：農林水産研究ジャーナル 32, 27-31 (2009).

11) 北方節夫, 吉田 守: 植物防疫 36, 478-481 (1982).

12) https://www.researchgate.net/figure/The-luminosity-functiondefines-the-sensitivity-of-the-human-eye-for-different fig1_262261737（2020年3月30日閲覧）

13）蟻川謙太郎他：研究成果第 535 集「害虫の光応答メカニズムの 解明及び高度利用技術の開発」, 農林水産技術会議事務局編, pp. 16-20, 2015.

14）弘中満太郎，針山孝彦：日本応用動物昆虫学会誌 58, 93-109 (2014).

15) 蟻川謙太郎：見える光, 見えない光一動物と光のかかわり, 共立 出版, pp. 68-70, 2009.

16) 弘中満太郎他: 昆虫科学読本一虫の目で見た驚きの世界, 東海大 学出版部, pp. 15-28, 2015.

17) 弘中満太郎他：植物防疫 72, 112-116 (2018).

18) 八瀬順也：植物防疫 72, 107-111 (2018).

19) 八瀬順也，森口彦彌：植物防㡯 74, 38-40 (2020).

\section{略 歴}

八瀬順也（やせ じゅんや）

生年月日：1963年 5 月 25 日

最終学歴: 愛媛大学大学院農学研究科

研究テーマ：虫の気持ちになって考える虫と人との付き合い方 趣味：現実逃避 